\title{
近代釜山で発行された民間新聞 『朝鮮時報』の資料価値
}

\author{
Jihyun LEE(李智賢: Co-researcher, Institute of Japanese Studies, Pusan National University) \\ 四 ochajlee@daum.net
}

(韓国)釜山大学日語日文学科講師。日本研究所土台研究事業共同研究員。日本近現代文学、戦争文学・植民 地文化研究。主著に『女力国を裏切るとき』(夏雨, 2017)、「1920年代釜山と京城の劇場街の植民性研究(『日語 日文学研究』2018)など。

\section{The Archival Value of the Joseon Sibo, a Pusan Newspaper Published in the Japanese Colonial Era}

This study will discuss the Joseon Sibo, a newspaper published in Pusan, Korea during the Japanese Colonial Era. In addition, it will examine a project that aims to create a database of articles published by the Joseon Sibo, which is being carried out by the Institute of Japanese Studies at Pusan National University.

The Joseon Sibo is an important source of data, the examination of which enables the better understanding of various cultural strands and literary works of the period, as well as the economic and industrial circumstances of both Korea and Pusan city, through which city modern culture and products were imported into Korea. The regional editions of this newspaper, including the Gyeongbuk, Jeolla, and Gyeonggi editions, are also a good source of data on the living conditions of various localities and the lifestyles of the people who lived in them.

The creation of the database of Joseon Sibo articles and advertisements will provide a new perspective on colonial culture and local history. In addition, through this database it is expected that the scope of research into the history of the colonial empire, which has been biased towards the Gyeongseong (Seoul) area, will be extended and that the quality of research in this field will improve.

Keywords Joseon Sibo(朝鮮時報), Non-goverment Newspaper(民間新聞),

Colonial Newspaper(植民地新聞), Busan(釜山), Colonization/ Imperial History（植民地帝国史） 


\section{1 はじめに}

近頃、植民地、帝国史研究と関連した日本語新聞の研究が盛んであるなか、日 帝強占期の地域性・植民性の特徵を具体的に伝えている地域新聞の資料価值がさ らに注目されている。

釜山大学日本研究所では、植民地朝鮮の釜山で発行された地域新聞、『朝鮮時 報』の記事・広告の総目録データーベース(以下、DB)を構築する事業 (事業遂行期 間2017年9月〜2022年8月)を遂行している。

本事業は、新聞記事の目録に加え、経済紙の特徵を持った『朝鮮時報』の広告も 含めた総目録DBを構築することを目指している。植民地の民間の生活を具体的 に伝えている『朝鮮時報』の記事・広告の目録化を行うことで、多様な分野の研究 に新たな視野を提供することができるとおもわれる。さらには、植民地・帝国史 研究、地域学の研究の活性化、新聞・メディア学などの後続研究などが期待され る。ここでは、『朝鮮時報』の資料的特徴と研究価値について紹介したい。

\section{2 植民地の地域民間新聞『朝鮮時報』}

植民地時代、帝国日本の移住政策により朝鮮に定住した日本人たちは、日本人 社会を作り、地域社会の声を代弁できる日本語新聞を発行した。日本人が植民地 朝鮮の各地で発行した民間新聞の種類は、およそ100余種に及ぶが、その中で、 連続的に紙面が保存され内容が把握できる日本語新聞は『京城日報』、『朝鮮新聞』、 『釜山日報』、『朝鮮時報』の4種類のみである。その中でも、『朝鮮時報』は『朝鮮新 聞』ととも発行時期(1892)が最も早い。

『朝鮮時報』は、商業、貿易、経済記事を中心とした商業新聞として出発した が、海外及び日本内地のニュース、釜山と周辺地域の政治・経済・社会・文化を 取り扱う総合紙であった。そして、植民地政策、文化政策のプロパガンダとして 活用されていた総督部の機関紙などに比べ記事内容の面において自由な方であ り、民間の生活を具体的に記録している。また、植民地初期に発行された影響力 のあるメディアとして社会・文化・文芸に関する記事が豊富である点もこの新聞 の特徵である。

中でも、他の日本語新聞より釜山と地方の事情を詳しく伝える記事が多いと いう点から、地域研究資料の不足を補うことができると思われる。このような 意味で、『朝鮮時報』は地域的に、階層的に、経済的に多様な観点から植民地の現 場が考察できる貴重な資料であるといえる。

なおかつ、『朝鮮時報』は釜山・慶南を中心とした朝鮮の全地域、日本と中国の 
1『朝鮮內發行新聞紙雜紙 分布詳細一覽』(1926)。

2『釜山日報』の1919年か ら1924年までの紙面は 消失されている。

3 朝鮮総督部編『朝鮮総督 部統計年報』(朝鮮総督 部, 1910), p.656.

4 釜山商業会議所編『釜山 総覧』(釜山商業会議所, 1912), p.336.
満州の地域においても配布されていた全国紙でもあった。1926年の資料によれ ば、『朝鮮時報』は釜山に限らず慶北、京畿、全羅、江原、平安、咸鏡道など朝鮮 の全域及び日本、中国にまで配布され、支社と支局は、京城、仁川、大邱、元 山、龜浦、三浪津、晋州、東萊、威興、馬山などの地域と日本の東京と大阪にま で設置されていたことが分かる。さらに、地域新聞でありながらその配布範囲 が広く、海外にまで読まれていた点は注目に值する。

このような『朝鮮時報』であるが、これまで資料の重要性が評価されなかった ことや、資料の可読性などの問題からあまり注目されてこなかったのが事実で ある。しかしながら、民間新聞『朝鮮時報』は各地域や地方のニュースを伝えてい た貴重なメディアであり、かつ釜山地域の他のメディアの空白死を補うことがで きる資料として、研究の価值は非常に高いのである。

\section{3『朝鮮時報』発刊の背景と資料の形態}

まずは、『朝鮮時報』の発刊された背景について調べたい。『朝鮮時報』の起源 は1892年7月に創刊された『釜山商況』にまで遡る。釜山の商況、つまり商業や経 済のニュースなどを報道するため不定期的に発行された新聞であったが、翌年 『東严貿易新聞』に改題され、1894年11月に『朝鮮時報』の題名で再創刊された。

一方、日帝強占期の3大日本語新聞の一つである『釜山日報』は、1905年1月に 『朝鮮日報』という名前で創刊され、1907年10月『釜山日報』に改題された。つま り、『釜山日報』より『朝鮮時報』の創刊時期が早いのである。なおかつ、初期の 『朝鮮時報』は『釜山日報』の発行部数を上回ることもあった。1910年末の1日当り の発行部数は『朝鮮時報』が2412部、『釜山日報』の方が2400部で、地域メディア として影響力が大きかったことがわかる。

『朝鮮時報』は熊本国権党の安達謙蔵が中心となって創刊された新聞で、『九州 日日新聞』の特派員であった安達謙藏が、当時釜山の総領事であった室田美文 と、釜山商業会議所の榊原茂夫の支援を得て創刊した。そして、初代の社長には 熊本国権堂の党員、『九州日々新聞』の記者であった高木末熊が就任した 4 。 


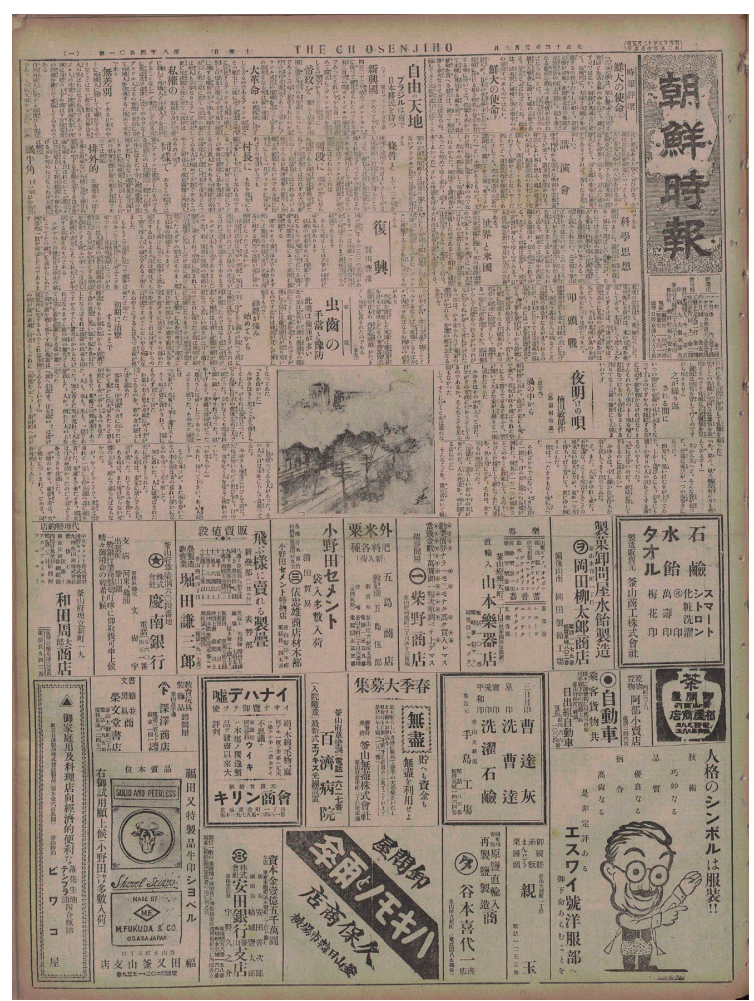

【図1】『朝鮮時報』1924年5月3日1面

朝鮮侵略を主導した熊本国権堂の勢力を中心に発刊された新聞であっただけ に、『朝鮮時報』は朝鮮での経済的・政治的な侵略及び勢力の拡張を目的とした日 本人たちの意図を読み取ることができる新聞でもある。植民地初期から、 1930 1940年代の戦争時代まで『朝鮮時報』はこのような論調で書かれている。

新聞は一日一回の発行で、紙面は4～6面で構成されている。現在国史編纂委員 会のホームページ(http://dbhistory.go.kr)に公開されている紙面をみると、1914 年から 1918年までは4 6面、1919年以降は4面となっており、日中戦争の時代 (1936年後半)からは再び6面に増やし、それが1940年の終刊まで続いている。

\section{4 資料の特徵と研究価値}

\section{1）地域・民間新聞}

地域の民間新聞『朝鮮時報』は、地方・地域の事情を具体的に伝え、朝鮮内日本 人社会の動向、社会実情、地域が持つ多様性と多層性の声が聞けるメディアで 
あった。さらに、帝国主義の立場ではなく、植民地の現場において植民地の政策 がいかに実現されていたのか、植民支配に対する民間の意識が把握できる資料で もある。

『朝鮮時報』には、地域の分野別ニュース、つまり社会の事件・事故、官庁の動 向、政財界のニュース、文化・芸術などの具体的な記事・広告が乗っている。さ らに、日本内地、朝鮮全国の各地域のニュースも収録し、単なる地域言論ではな く、植民地朝鮮の全地域の様子を伝え、植民主義の実相を確認することができ る。

また、民間の新聞社として、新聞社の経済的な利益のため、新聞の発行部数 を増やすための努力をしたという点も、民間新聞ならではの特徵であるだろ う。このような側面は、連載小説、広告などからも読むことができる。1910年 代初期は、多くの新聞が創刊され隆盛した時期であった。新聞社が成長し、生き 残るために、読者を獲得するための競争が繰り広げられた時期でもあった。『朝 鮮時報』においてもこのような面が色濃く浮き彫りにされる。

2）商業経済紙・広告

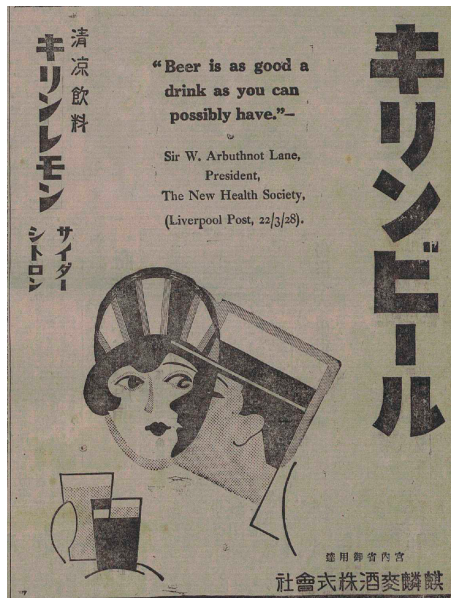

【図2】1929年6月15日

『朝鮮時報』は釜山の政治・経済・社会・文 化を取り扱った総合紙であったが、その母 体である新聞は商業・経済のニュースを報道 する目的で創刊された『釜山商況』、東亜貿 易新聞』であった。そのため、『朝鮮時報』も 他の新聞より商業・経済記事の量が圧倒的に 多かったが、次第に政治・社会・文化の記事 も増やしていった。

商業の記事には、穀物、食糧、生系、糖 粉など水産業、農業、鉱物業の品物の輸入 輸出状況と海外の経済ニュースなどを伝える 記事がみえる一方、商業施設の設置、学校組 合設置など、政治・経済の土台を構築し植民 地を経済的に侵略する様相などもみられる。また、日本と地域の資本家、政治 家、経済団体の近況及び日本の皇室のニュースなども伝え、日本内地と植民地の 結束を強めつつ、植民地の発展像、近代の文明などを伝え、新聞読者に日本統治 の効果を宣伝する内容も含まれている。

このように、商業新聞の『朝鮮時報』には、近代文物の輸入、植民地の経済の 様相を分析できる資料が豊富であるが、さらに特徵的な点は他の新聞よりく広告 


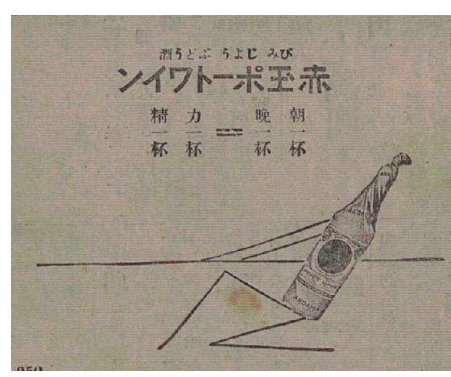

【図3】1929年6月16日
欄〉の比重が大きいという点である。つま り、医療機関、金融、生活用品、嗜好品、映 画、服装などに関する多様な広告が掲載され ていて、植民地初期の近代の生活文化、経済 の流れ、近代産業発達の様子を読み取ること ができる。

例えば、ビール、葡萄酒、砂糖などの食 料品や、化粧品、タバコ、洋服、歯磨き粉な どの商品からみられる近代初期釜山の韓国人

及び日本人の生活像、近代文化の様子、植民地での経済政策などが読み取れる。 ビールと葡萄酒のような酒類、嗜好品の広告をみると、酒類の販売量を増やすた めに、健康食品として宣伝する広告・記事もあって、当時の消費政策を分析する ことができる。図2、図3は、ビールとワインを健康食品として宣伝している広 告である。

\section{3）多様な文化・文芸記事}

釜山は、近代文物・文化輸入の空口であったため、『朝鮮時報』には社会・文 化・文芸に関する記事も豊富である。新聞というメディアは、移住日本人にとっ て文化と知識の交換、享受の場でもあった。

『朝鮮時報』は、文芸欄にも力を入れており、1日2回の連載小説を揭載し、『時 報俳壇』、『時報詩林』、『短歌』などのコーナーも備えていた。連載小説は、日本 内地で人気を集めた流行作家たちを招いて揭載したり、娱楽性を持った歴史小説 を掲載するなど、固定読者を作るための努力をしたようにみえる。

映画の場合は、常設館で上映される映画の広告が毎日掲載されていたことか ら、また映画を宣伝する広告・記事などから、当時の劇場街の文化の様相を分析 することができる。近代の釜山は、近代式の劇場が建てられ、海外の新しい映画 が公開されるなど劇場文化を率引する映画の都市でもあった ${ }^{5}$ 。1910年代の釜山 の劇場街は上映される映画の数、観客の規模などの面ににおいて京城に劣らぬぐ らいであった。

1910年代の日本と朝鮮でも大ヒットしたハリウット映画『名金』の映画小説 は、1916年に『朝鮮時報』で初公開され40回に渡って掲載され、人久に広く知ら れることになった。当時の『朝鮮時報』は、新しい文化を導入・紹介する通路でも あった。

さらに、戦前まで日本出版史上初めて発行部数100万部を突破した国民的雑誌 であった『キング』を広告する記事もみえ、『朝鮮時報』が日本内地の文化と密接に 
関連していることがわかる。

釜山で上演された映画や劇の中には、全国初公開の作品もあり、『朝鮮時報』 から文化輸入の玄関口であった釜山の近代文化の様相と、中央文化との比較分析 も可能である。さらに、国境である釜山という都市が持つ植民地近代性と文化の 様相についても考察できるとおもわれる。

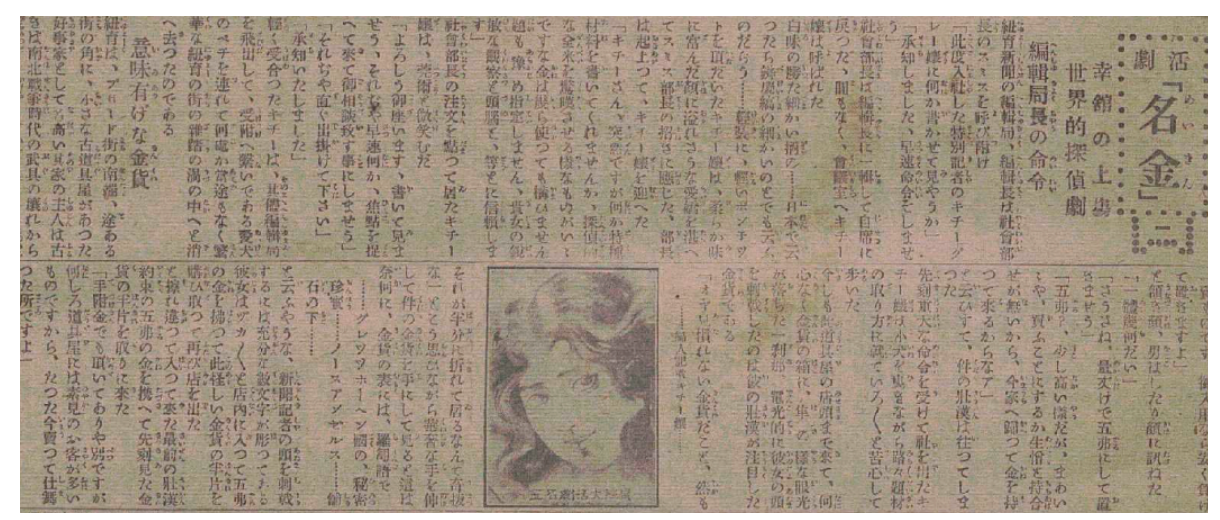

【図4】映画小説「名金」第1話(『朝鮮時報』1916年7月22日)

\section{4）読者欄}

『朝鮮時報』のう一つの特徵は、〈読者闌〉が備えられている点である。〈読者 闌〉では記事内容に対し、読者が自分の意見を投稿した内容が見られる。また、 地域の衛生、売春、疫病など地域の事件・事故の告発と、株式、道路の工事、映 画館の休館などについての投稿もある。

それに加え、〈読者文芸〉、〈時報俳壇〉のような、読者が参加できるコーナー を設けるなど、新聞の読者が積極的に参加できるようにした。このような読者 コーナーを基に、『朝鮮時報』の読者層の分析、世論の動向などが分析できると思 われる。

\section{5）地方版}

さらに、『朝鮮時報』は、当時の新聞としてはめずらしく、釜山の周辺の地域 のニュースを伝える「地域言論」の役割も果たした。「地方版」の記事は、釜山を含 む慶尙南道・慶向北道の記事だけではなく、全羅道、忠清道、京畿道、黃海道、 平安道、咸鏡道の記事も取り扱い、各地域のニュースを集中的に報道している。 左の画像のように地方版は『朝鮮時報慶北版』、『朝鮮時報晋州版』、『日刊慶北 
版』、地方版』などのタイトルで別の紙面で紹介された。このような地方の ニュースを伝えるコーナは、他の新聞ではあまりみられない特徵である。

このような「地方版」では、中央紙では取り扱われてなかった各地域のニュー ス、事件事故、経済・社会状況、施設案内、人事移動、有名人の近況などの記事 と、地方の歴史、団体などを紹介するニュースを、詳しく報道している。

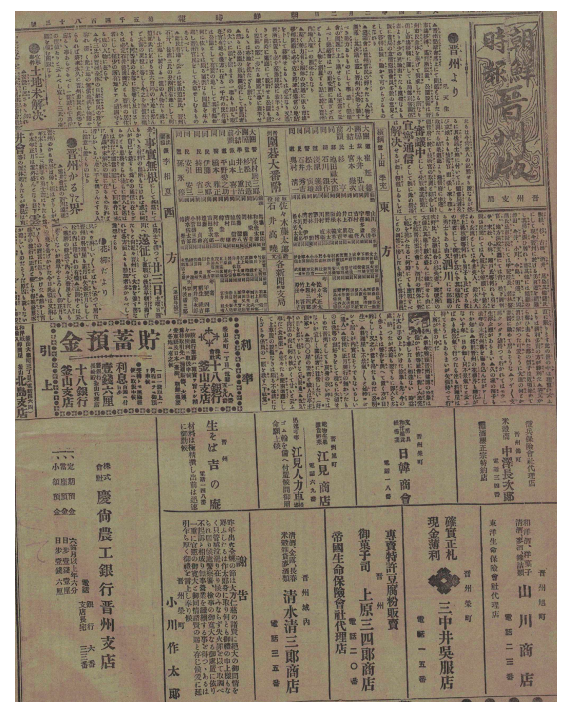

【図5】『朝鮮時報晋州版』(1915年2月2日)

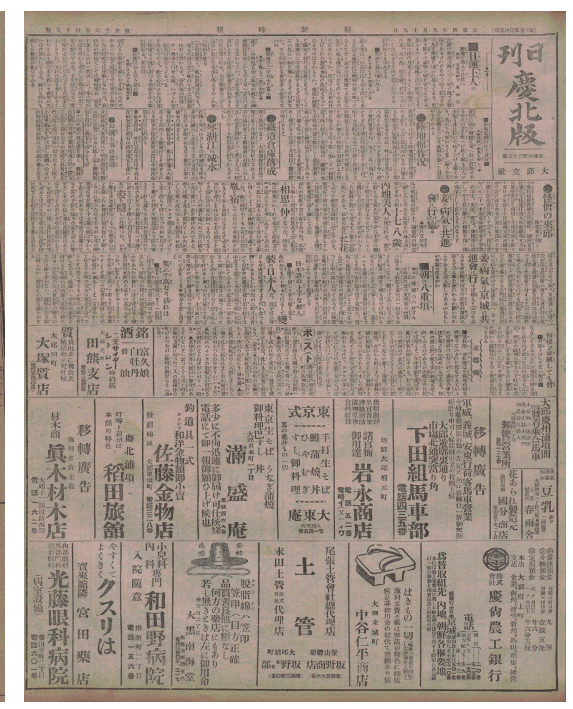

【図6】日刊慶北版』(1915年8月19日)

\section{5 『朝鮮時報』の記事・広告タイトルのDB構築}

本事業は釜山発行の日本語新聞『朝鮮時報』の記事と広告タイトルの目録化を行 うことで、諸々の学問の研究の土台を創ることを目的としている。広告の目録の DBは、従来の新聞のDBにはなかったことで、近代文物の輸入及び、当時の生活 文化の研究、また植民地での経済的支配政策の研究など、植民地文化・地域史の 研究に新たな地平を開いてくれることと期待される。

まず、記事のDBは従来のような記事の題目/表題語のみのDBではなく、類 型・時代・地域・キワードなど項目を細分化し、検索機能を強化したDBを提供す る。また、日本語新聞DBの記事原文の翻訳の䛊謬のないよう、翻訳の相互点検も 行い、信頼性の高いDBを製作する。さらに、従来のDBは記事タイトルだけでの 検索であったため、記事内容までは把握しにくかったが、このDBではキーワー ドを使って新聞記事の内容まで検索し、記事原文の内容を把握できるようにし た。 
また、新聞記事とは別に広告目録のDBも構築する。これまでは、新聞記事以 外に、広告のDBは構築されたことがなく、当時の社会雾囲気や文化、植民地の 経済政策の実現の様相、一般市民の生活像までは把握しにくいという限界を持っ ていた。

商業・経済紙の特徴を持っている『朝鮮時報』は生活の記事、広告の数が多いた め、植民地の生活像、文化の輸入と流行、近代初期の産業の発達状況を把握する 資料の宝庫でもある。広告欄における、金融、商業、演芸、文化、生活、美容、

教育、宿泊、食品、薬品などの多様な資料と広告を主題別、類型別に分類し、近 代釜山のの文化と生活を把握できるようにする。

このように新聞資料を活用した研究の土台を作り植民地・帝国史・地域史研究 の進展及び拡張に一助したい。

\section{6 終わりに}

以上の通り、近代釜山の日本語新聞『朝鮮時報』の記事・広告の総目録 $\mathrm{DB}$ 構築 することにより、地域学研究の資料を提供し、植民地・帝国史研究の基盤を作る ことができると思わ机る。本事業は、記事タイトルだけではなく、キーワー ド、主題などでも記事内容が検索でき、日韓両国語による検索も可能な高い品質 のDBを構築し、日本学、日本文化学の研究者のみならず一般人もが活用できる資 料を提供することを目指している。それによって、植民地時代への理解や分析を 深める機会と、東北アジア研究への新しい視野を提供したい。

なおかつ、本事業を通して、植民地・帝国史研究の範囲が京城中心の文学・文 化に偏っていた現状を打開し、地方までに研究領域を拡張することで、植民地時 代の全体像を把握することが可能となるのであろう。さらには、東北アジア研 究のさらなる進展にも一助となることを期待している。 